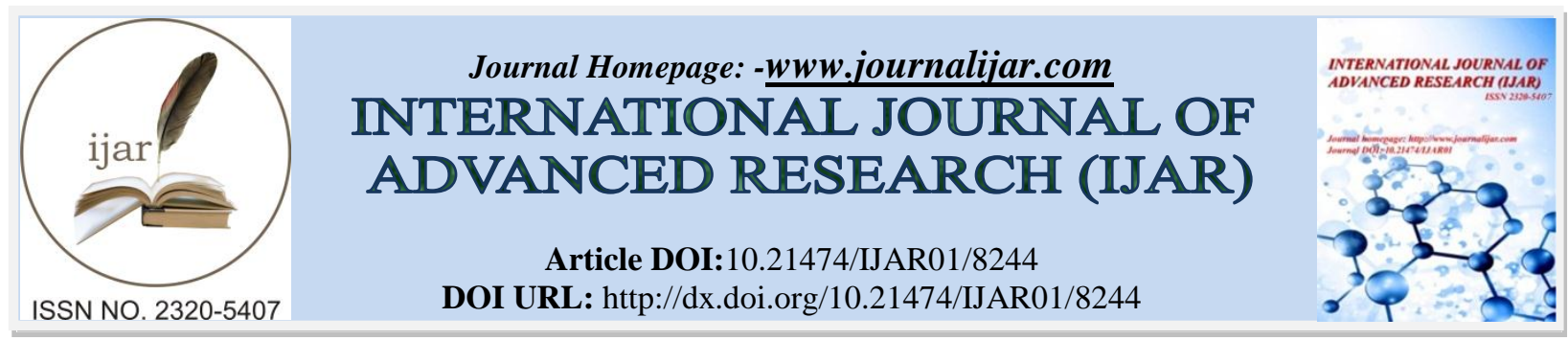

RESEARCH ARTICLE

\title{
PEACE EDUCATION, MODIFIED EDUCATIONAL CURRICULUM AND REDUCTION OF VIOLENCE AND TERRORISM IN NORTHERN NIGERIA.
}

\author{
Department of Political Science and Public Administration Babcock University, Ilishan, Ogun State.
}

\section{Manuscript Info}

Manuscript History

Received: 20 October 2018

Final Accepted: 22 November 2018

Published: December 2018

\begin{abstract}
The first recorded religious violence in Nigeria was in Kano in 1952, then Maitasene crisis of early 1980s and the emergence of Boko Haram in 2002in the Northern part of the country while efforts to institutionalize peace in a badly divided societies has a herculean task. The absence of peace education in theeducational curriculum Nigeria is worrisome leading to indoctrinated youth serving as vanguard for violence.The paper therefore examined the place of modified educational curriculum in instilling ofculture of peace to minimize violence. The study was descriptive and relied on secondary data sources.It found that the division along ethnic and religious lines made nationalism a mirage while the governments failed to develop the political will to guarantee good governance.The study concluded that the neglect of peace education in the nation's educational curriculum is a serious challenge while its inclusion could inculcate a culture of peace to curb terrorism and other form of violence. It recommended the inclusion of peace education in the nation's educational curriculum and the training of instructors as well as adequately funding and monitoring the program to ensure that violence is minimized particularly in Northern part of Nigeria and the nation. Finally, the support of other actors in the educational sector is imperative to complement instruction from schools.
\end{abstract}

Copy Right, IJAR, 2018,. All rights reserved.

\section{Introduction:-}

Insurgence and terrorism are often loosely used or assumed to mean the same thing. There is no doubt that insurgency and terrorism are politically motivated violencethey don't contain similar strategic choices and organizational structures. Terrorism is politically motivated violence or the threat of violence that is directed against non-combatants by sub-state actors.Insurgency on the other hand is a struggle between a non-state actors and the state actors (government) in which the non-state actors uses political resources and violence involving protracted political as well as military activity, the use of irregular military forces with the intension of mobilizing support for its course internationally and relied on the support of a section of the population with a view of destabilizing or taking over government Wheat (2011). With specific reference to Boko Haram, the sect contains the attributes of insurgence and terrorism, contrary to many definitions of terrorism, Boko Haram had gone more step further in taking over territory as fourteen Local Governments were captured by the sect as at 2014. In addition, the attacks were not limited to non-combatants alone. Hence, the definition of terrorism is dynamic and must take into consideration the modus operandi of a particular group.

Corresponding Author:-David Oladimeji Alao.

Address:- Department of Political Science and Public Administration Babcock University, Ilishan, Ogun State. 
Since Boko Haram adopted violence in 2010 as a mean of conducting its activities, the effects have been disastrous within Nigeria and beyond. The Nigeria Watch Project Fifth Report on Violence (2015) claimed that Boko Haram onslaught and military operations claimed more than 23,000 deaths. Contrary to the above, Tukur (2017) quoting the Governor of Bornu State put the figure at over 100,000. In the same report he noted that over 2,114,000 people were internally displaced as at December, 2016.

Apart from the list of casualties, it is disheartening as reported by Buari (2015) and further confirmed by the PM News (2016) that Children and teenagers were recruited by the sect as child soldier positioned in the front line as canon folder to deter the advancement of the Nigerian troops and used for suicide attack. The young underage girls were converted to wives. There is no doubt that poverty and wrong educational and religious indoctrinations among others play a significant role in the recruitment and operation of Boko Haram. However, the educational curriculum in Nigeria has not provided for peace education at all level. The implication is that what is taught concerning the need for peaceful coexistence in Nigeria is subject to the whims and caprices of the instructors and most likely with perverted view on the role of religion or ethnicity in enhancing peace in Nigeria.

Hence, this study assumes a modified educational curriculum revolving around inclusion of peace education may go a long way to address the insecurity in Nigeria and with specific reference to insurgence and terrorism in the North East,Nigeria. This study views peace as a necessary condition for socio-political and economic development in any nation, it is not accidental but planned, systematically executed and based on sustained action for it to be enduring. Educational curriculum, in effects, constitutes just an aspect of peace education as it revolves around those instruction through formal educational system. On the other hand, peace education covers every aspect of human life such as religion, family and peer group among others so that the orientation and the behavioural pattern of every individual will be supportive of peaceful coexistence.

This study therefore set as its objective the review of educational curriculum in Nigeria since independence, therole of modified educational curriculum in curbing terrorism and the challenges associated with it. The study adopted a descriptive approach and relied on secondary date sources.

\section{Theoretical framework:-}

The study adopt the Integrative theory of peace to capture the need for a modified educational curriculum and curbing the insurgence in the Northern part of Nigeria. Danesh (2006) contributed significantly to the popularization of Integrative theory of peace. In his work, Danesh (2011:22) observes that the approach is based on the concept that peace is:

"a psychological, social, political, ethical and spiritual state with expressions at intrapersonal, interpersonal, intergroup and international areas of human life and that all human states of being, including peace, are the outcome of the main human cognitive (knowing), emotive (loving) and conative (choosing) capacities, which together determine the nature of our worldview"

Duffy (2000) with specific reference to Northern Ireland notes that peace education efforts aimed at creating a culture of peace and concludes that it is difficult to be optimistic about the long term possibilities of promoting change in conditions of conflict unless a dynamic model of education is introduced that will encourage young people in Northern Ireland to question the traditional sectarian values of their homes.

The Integrative Theory of Peace consists of four sub theories. The first concentrated on peace as a psychosocial and political, moral and spiritual condition of human existence. Second, it is seen as the main expression of a unitybased worldview. Third, is that the unity-based worldview is the prerequisite for creating both a culture of peace and a culture of healing and lastly, as a "comprehensive, integrated, and lifelong education within the framework of peace as the most effective approach for a transformation from the conflict-based metacategories of survival-based and identity-based worldviews to the metacategory of unity-based worldview" Danesh (2016:61).

The theory agrees with the human needs theorists believing that the satisfaction of human need is imperative for survival, safety and security. This is in view ofthe imperativeness of human quest for freedom, justice, interconnectedness and human search for meaning, purpose and righteousness. Thus Danesh (2011:22) observes that: 
"peace is the ultimate outcome of our transition from self-centered and anxiety-ridden insecurities of survival instincts and the quarrelsome, dichotomous tensions of the identity-formation processes to a universal and allinclusive state of awareness of our fundamental oneness and connectedness with all humanity, in fact, with all life".

This explains why Moscovici (1993:160-70) and Hägglund (1999:190-207) conceive of Worldview, Education, and Power as the foundation of every culture, a concept they calls "social representations," and "constitute discursive complexes of norms, values, beliefs, and knowledge, adhered to various phenomena in human beings' lives" respectively. In effect, Danesh (2011) views world notes that one of the primary goals of education is its invaluable value to the formulation of our worldview as it creates the essential framework for human life processes which consists of human "thoughts, feelings, choices and actions". World view therefore impact on humanity as is view from conflict dominated perspective whether occasioned by ethnic, religious or environmental conditions as noted among others by Van Slyck et al., (1999). This same view is expressed by Pettigrew (1998) and Allport, (1954) in "contact theory", found in Rouhana \& Bar-Tal, (1998) on "collective narrative" as well as Sonnenschein et al., 1998) in "dialogue". This explains why Firer (2002) perceive peace education as the only route to true civilization and true civilization is both peaceful and peace creating.

Relating the theory to the need for modified educational curriculum as a means of curbing insurgence in Nigeria, it is imperative to note that the world view of significant number of Nigerians is based on mutual suspicion, distrust, perversion of ethnicity and religion as a mean of political mobilization and access to centrally allocated resources. Hence, younger generation are consciously or unconsciously indoctrinated and socialized into perverse and acrimonious relationship within and between ethnic and religious conglomeration.The goal of modified educational curriculum is to correct the perverse view already absorber from childhood to adulthood that shape the orientation of many to the events around them.

The basic challenge of the theory is that while the creation of world view is essential for the citizenry, the question with specific reference to Nigeria is who are to compose the elements that will make input into the modified education curriculum from primary to tertiary level. While the family, religious groups and educational institutions among others are required to play a noble role, the selfish agenda by each of these actor might hinder the development of world view. In addition, such a goal is not a one-time attempt at peace but a long time project subject to modification to meet the dynamics of the society.It is however doubtful if Nigerian system is supportive of that arrangement as government business is not seen as a continuity while any government in power often attempt to disassociate from previous government programs no matter how good they are. Nonetheless, the Integrative Theory of Peace provides a comprehensive approach by combining other essential theories of peace to adopting modified educational curriculum as a means of curbing insurgence in the Northern part of Nigeria.

\section{Conceptual Review:-}

\section{Insurgence and Terrorism:-}

There is tendency to confuse terrorism with insurgence and the two terms have been used interchangeably and erroneously to mean the same thing. An insurgency is best describes as a movement but political in nature with a specific objective. On the other hand, terrorism is best seen as one of the methods available to pursue the goals of the political movement. The implication is that in a situation of insurgency, terrorism might serve as one of the available tactics. Terrorist rely largely on the use of force, insurgent might not adopt terrorism as a method while terrorism when adopted is expected to inspire further resistance, tarnishing government image and as a means of mobilizing support for their cause.

Insurgency has as its objective the challenge of the sitting government by a way of taking control of all the territory or part of it or forcing government to concede the sharing of political power as manifested in Zimbabwe and South Sudan. This explains why Hornby (2006:775) views insurgency as "an attempt to take control of a country by force". This implies that insurgency requires active support of a section of population, external support or recognition to achieve this objective like the situation in Syria and Libya. On the other hand, terrorists might in some case not consider the above tactics as essential while they often refer to their group or sect as freedom fighter or activist. As pillar (2011) and Cunningham (2003) note, terrorism relies on sensitization of the public to the weakness of the government thereby draw public support to their cause like the case in Adamawa and Bornu States where members of the public during Jonathan regime sought refuge under Boko Haram cover due to the perceived weakness of the government to deal with the challenges. Nevertheless, the basic difference between insurgency and terrorism could be understood further based on the intent of the actors. 
Boko Haram as a terrorist group combines the elements of an insurgence by seeking and actually controlled fourteen Local government Areas in the North East and aspiring to create an Islamic state. This in effect will make the paper focus largely on terrorism.In view of the fact that the manifestation and modus operandi of terrorists is not static but dynamic, the understanding of the term keeps expanding. For instance, pillar (2011:13\&14) came up with four elements of terrorism. These include "premeditation action rather than momentary rage or impulse, political motivation rather than criminally motivated violence, monetary gain or personal vengeance". Pillar adds that the targets "are noncombatants and the perpetrators are either sub-national groups or clandestine agents".

In contemporary time, terrorists like Boko Haram and ISIS no longer focus their attacks on non-combatants but on the military and paramilitary forces. By implication, terrorist don't obey the rule of war, hence Jenkins in Kegley, 1990:29) observes "that terrorism's relationship to war is closer to war crimes than legitimate military operations". This explains why Cunningham, (2003:12) notes that terrorism when applied non-state actors, is largely a strategy for revolution directed at influencing and destabilizing political systems and at extreme end to overthrow government largely a method adopted the weak group to attack the strong. Jenkins in Kegley, (1990:36) therefore identified six common strategies often adopted by terrorists which were found to be true of 95 percent of all incidents examined that included "bombings, assassinations, armed assaults, kidnappings, barricade and hostage situations and hijackings". Situating this within the purview of Boko Haram onslaught, additional tactics include bank and market raid as well as cattle rustling.

In identifying who is a terrorist, Sick in Kegley, (1990:52) observes the complexity in that "The cliché that one man's terrorist is another man's freedom fighter". In effect, it is a function of the perception of individual involved. This agrees with Wilmot and Hocker, (2001:28) from psychological perspective that "our behavior (B) is a result of who we are (our personal dispositions-our 'personality' 'P') and the situations ' $S$ ' (circumstances and environment) that we find ourselves in $(\mathrm{B}=\mathrm{P}+\mathrm{S})$ ". In addition, Volkan, 1990:31) connects the understanding of who a terrorist is with the needs theory that every individual has "a deep-rooted psychological need to dichotomize and to establish a system of enemies and allies".

Crenshaw in Sick, 1990:53) defines terrorism as the "deliberate and systematic use or threat of violence to coerce changes in political behavior. It involves symbolic acts of violence, intended to communicate a political message to watching audiences".

The paper agrees with Cunningham, (2003:25) that "it is so broad that almost any act of political violence could be conceived to fall within the boundaries of this definition". If however one pursue the line of thought of Pillar, (2001:18)by viewing terrorism as a method to the neglect of the actors or their objectives,one can be seen as subjective. Hoffman, (1998:43) therefore defines terrorism as "the deliberate creation and exploitation of fear through violence or the threat of violence in the pursuit of political change"

On the other hand, the Department of State and the Central Intelligence Agency use Title 22 of the U.S. CodeSection $2656 \mathrm{f}$ (d) to define terrorism as "premeditated, politically motivated violence perpetrated against noncombatant targets by subnational groups or clandestine agents, usually intended to influence an audience". As for Department of Defense, terrorism is viewed as 'The unlawful use of - or threatened use of force or violence against individuals or property to coerce or intimidate governments or societies, often to achieve political, religious or ideological objectives". The State Department definition focuses on premeditation and the noncombatant status of victims, it refuses to acknowledge the role of the state actors or the psychological affects and the illegal nature of such acts.The FBI addresses the illegal nature of the acts, but it does not address the actors Cunningham, (2003:29).

The implication of this analysis is the difficulty of evolving a single and an all-encompassing definition of terrorism. With specific reference to Boko Haram, it is view as a premeditated politically motivated direct violence, with religious pretense, without restricted targets that capitalizes on the tensed political, ethnic, religious and economic challenges in Nigeria as a platform for mobilization withan intent to destabilize the country and convert it to Islamic nation.

\section{Peace and Peace Education:-}

It is a truism that most people want peace but the path to peace is not appreciated as people are scared of others taking advantage of them. Peace is often described as the absence of war. For Einstein (1988), "Peace is not merely the absence of war but the presence of justice, of law, of order - in short, of government". This explains 
whylbeanu (2007:3) opines that such a conclusion that peace is not the absence of war or conflict is "tautological and circular in logic in that there is peace because there is no war and there is war because there is no peace". More than that, Ibeanu (2007:3) failed also to take into consideration a graveyard peace or forced peace by suppression of individual's rights that might be terrible as a situation of war. Goodhand and Hulme (1999) from Biblical perspectivequoting Isiah $2: 4$, views it as "the beating of swords into ploughshare".

It is therefore essential note that a situation devoid of excessive structural and cultural violence will curb the propensity of direct violence and by implication capable of enthroning or enhancing the capacity to remain and live peacefully Galtung (2000). Hence, Integrative Theory of Peace in Danesh (2001:24) posits that:

"peace has its roots at once in the satisfaction of human need for survival, safety and security; in the human quest for freedom, justice and interconnectedness; and in the human search for meaning, purpose, and righteousness"

This might have informed the Jewish notion of peace to mean shalom which further translate to mean well-being, wholeness, abundance and harmony within one self and in social relationship and in no way preclude the persistence of conflict between the Jews and the Palestinians. As Danesh and Danesh (2001) observe among other elements, peace is "a psychosocial and political as well as a moral and spiritual condition" through which individuals live a fruitful and secured life.

The UNICEF (2011) defines peace education as"the process of promoting the knowledge, skills, attitudes and values needed to bring about behaviour change that will enable children, youth and adults to prevent conflict and violence, both overt and structural; to resolve conflict peacefully; and to create the conditions conducive to peace, whether at an interpersonal, intergroup, national or international level".

By implication as noted above, peace education is expected to span beyond class room experience but a livelong program of learning on how to prevent, manage or resolve conflicts in order to make it productive rather than destructive bearing in mind that the seed of conflict is often located in human relationship. This in effect led UNICEF (2011) identify the activities associated with peace education inclusive of creating needed support for peace education and education for conflict resolution initiatives nationally. This will further involve the development of nationally based educational curriculum, educational materials, and teaching manuals as well as training program. The curriculum should also accommodate sport for development as an instrument for peace and peace and disarmament education. In a nation like Nigeria, it has been observed that the major unifying factor is sport particularly football. The essence is that peace education is multidimensional, multidisciplinary and multifaceted and not straight line jacket approach can bring about desirable result. This therefore requires a comprehensive, sustainable, inclusive and transformative framework which must be situated within worldview as observed by Danesh (2006). The approach must be able to accommodate the interest of each segment of the society inclusive of the needs of each age group subjected to periodic evaluation and review to ensure that it meets the established goal. Therefore, human relationships is the heart of peace education with a view of transforming man from sentiment and conflict dominated reasoning to that of love and accommodation.

In effect, though the scope of this study is on educational curriculum, for it to achieve result, the citizenry as a whole must be accommodated as to produce a new "us". This implies at family level, school, religious gathering, community association, the messages of peaceful coexistence and tolerance are indispensable. This agree with the position of Danesh (2006) that "the prevalence of crisis globally calls for appropriate and time action to be given to peace education to save the present generation and the future ones from the destructive influence of war and conflict". This could be partly be achieved if right from cradle children are taught of peace education and practiced at home, school, religious settings and community at large.

Harris in effect identifies ten goals for effective peace education:

...to appreciate the richness of the concept of peace; to address fears; to provide information about security systems; to understand violent behaviour; to develop intercultural understanding; to provide for a future orientation; to teach peace as a process; to promote a concept of peace accompanied by social justice; to stimulate a respect for life; and to end violence (Harris, 2002:20).

These goals, though may be elastic, if sincerely pursued has the tendency of making peace education effective. 


\section{Educational Curriculum:-}

Education spans beyond pursuing a course of study or getting a degree or chain of degrees. It is a learning experience with the goal of producing change in our world view. Therefore, as observed by ACS Distance Education (2011) that"It isan inherent and permanent change in a person's thinking and capacity to do things". The objective of getting educated in contemporary era must span beyond getting a high class degree to serve as meal ticket or the understanding of content knowledge or use of new technologies but must include the mastery of the learning process to prepare individuals to cope with future challenges by been adaptable to events within the nation and beyond.

Tyler \& Hlebowitsh (2013) views curriculum as a planned instructional guide or a written document consisting of content with planned learning experiences directed at achieving desired and intentional goals or ends. The development of educational curriculum cannot but involve a process through which various actors are engaged in evolving a workable blue print to guide learning at all levels. In this study, the focus is on developing an encompassing educational curriculum that may be of value in reducing insurgency and terrorism in Nigeria.

Curriculum is largely used to explain or describe primarily the goals, objectives, or plans that may be differentiated from the methods, materials, and assessment in educational development.According to Kimbre (2016), Curriculum development "determines the type of information that is taught in schools, as well as how it will be taught, and who will teach it". He developed for stages of curriculum development consisting of planning, content, implementation and evaluation. As simple as the four stages look like, in a multi-ethnic and multi-religious nation where national integration is still a big problem, the issue of developing educational curriculum may develop a larger than life posture and become a source of conflict that might be difficult to manage.

In curriculum planning has to do with the determination of the basic issue in focus and a team to work on it is formed. This might assume political undertone in Nigeria where the focus is shifted from the issue to the number of Christians versus Muslim involved and may as well truncate the noble goal particularly when there is lack of political will to remain focused. In respect of the content of the curriculum, attention is expected to be centered on the intended outcomes of the curriculum Kimbre (2016) further noted the program's unifying framework as well as the new methods of teaching the content that have been created.

For the implementation stage, this involves the new designs and methods to be adopted. The teachers or instructors should be adequately trained in respect of the new curriculum and what adjustment could be made to achieve the expected result which implies that the process is not static but change of strategy must be anticipated. Finally, evaluation is required to assess the effectiveness of the instruction in line with the curriculum developed. Like in implementation stage, there is the need for update to cope changing global system as new contents might be required, retraining and new designs must be introduced.

There are many models of educational curriculum development. For instance the Tyler modelhas four stages consisting of determining the objective of the school and class, developing learning experience, organizing the experience and evaluation. The goal regardless of the model is to ensure that the curriculum achieve the stated objectives.

Many actors play major roles in the educational sector but the political reality influences the development of educational curriculum. Actors include the parent, pupils, educational institutions, global direction in education, politicians, religious leaders and government. The success of evolving a suitable educational curriculum that will accommodate peace education as a means of curbing terrorism is largely a function of the inclusiveness at every stage thereby making the actors supportive or at worse neutral.

\section{Educational Curriculum and curbing insurgency and terrorism in Northern Nigeria}

A critical evaluation of the social relationship existing in Nigeria will leave no one in doubtthat it emphasizes divisive elements than our common identity.Among the basic objectives of education is to guarantee mental and physical health through which an individual can develop knowledge and skill to cope with life challenges, attain economic prosperity, social upliftment and enhance the capacity to achieve political stability Hamid (2012). In individual, it is expected to engender logical thinking, rational attitude which is attainable through balance intellectual development and positive value inculcation which is glaringly deficient in Nigeria as a whole. 
The understanding of the above makes a modified educational curriculum with emphasis on peace education at all levelsimperative as one of the ways to institutionalize peace culture in Nigeria. For instance, one of the commander of Boko Haram Auwal Ismaeela who voluntarily surrendered to the government in an interview with the PRNigeria News Agency as reported by The Nation (2017, August 28)was quoted saying that "It is unfortunate that I was brainwashed and misled not only on some abductions but in the killings of my own people that were innocent". He further added that misleading sermons and barbaric indoctrination was responsible for his participation in acts of terrorism which this study argues could partly be corrected through corrective educational instruction through modified educational curriculum in educational institutions.As noted by UNESCO (2017) global citizenship education should be integrated into existing educational curriculum consisting of civics education, history, and political development to change the perception of the students beyond the narrow perspective of courses currently offered..

A modified educational curriculum if it is sincerely pursued and executed has the tendency to minimize the pull factors such as financial gains, exhibition of braveness and misinterpretation and misapplication of religious injunctions particularly in Islam. This has the tendency to discourage the recruitment into the sect while the educational instruction as noted by UNESCO (2017)will create awareness, fosteringrespect for others, and institutionalize and sustain cultures of peace and dialogue. The study argues that this might not be a panacea for preventing extreme violence as manifested in Boko Haram since very well educated individual might share the philosophy of violence, it has to be complemented with informal education that must emphasize peace. This explains why Mark (2016) remarked that the quality education must accommodate two key components consisting of "a sense of belonging to human community (inclusiveness), and promoting teaching and learning universal values of dignity, democracy, diversity and sustainable development". This position agrees with Danladi (2008) agrees that an alternative strategy of Social Responsibility must involve total mobilization of the social, cultural, economic and political institutions, supported by individuals and groups to make pace education a success

The educational curriculum can be tailored to meet the local context of the environment in question as a means of curbing terrorism rather than generalist approach. By implication, such a curriculum cannot but be fashioned to respect the religion of the society and meet the social aspirations as well. This is expected to receive the cooperation of the people when government agencies involve such as the religious leaders, traditional institution and parents as well as teachers among others are involved in the process of planning and execution of the new curriculum. It therefore imperative that existing network as observed by UNICEF (2016) should be used to give legitimacy to the project and guarantee inclusiveness.

A modified educational curriculum is expected to redirect the attention of students to engage in productive and positive endeavors within the community and enhance their capacity to key into actions that support peace or engender a sense of collective responsibility for the safety and development of their community rather than serving as agents of destruction. This is achieved if the modified educational curriculum at childhood stage is further reinforced at higher stages through cognitive, social and communication skills that focus on peace and respect for human rights and dignity.

The modified educational curriculum is not only to equip the students with positive reinforcement but also the teachers and instructor who must first and foremost change their worldview in respect of what it takes to institutionalize enduring peace. If the teachers are well taught of the need for peace education and such is embraced, it enables them to teach what they believe in rather than merely working for salary as rightly noted byChazin \& Ledford (2016).

Peace education embedded in a modified educational curriculum has the tendency to change the perverted view of many students that were inherited and communicated to them from childhood and transmitted from one generation to another. The quality of instruction to achieve this goal is expected to created opportunity for dialogue and seeking clarification in areas of controversy that might encourage nationalistic spirit rather than parochial citizenry.

A modified educational curriculum is expected to produce a complete educational experience that enhances the capacity for creative thinking rather than mere indoctrination by selfish and 'ignorant' individuals. Such an experience among students will exposure them to mechanisms to deal peacefully with diversity and collaborate in finding joint solution to problems rather than antagonism. While secondary education can reinforce positive learning at primary school level, universities are centers of ideas as noted by UNICEF (2016) where "many different 
ideologies, opinions, and viewpoints are shared and debated". This in turn will produce healthy exchange of ideas and broaden the horizons of students in preparing them for future tasks.

Hence, the modified educational curriculum according to Danesh (2011:10\&11) is to inculcate a culture of peace by creating "violence-free, bullying-free, harmonious, and peaceful environments throughout the school community". In addition, it will ensure a culture of healing by"creating an environment conducive to helping all members of the school community to gradually recover from the negative effects of conflict and violence that they may have experienced in their lives" and culture of excellence by institutionalizing "an environment conducive to excellence in all aspects of the lives of members of the school community: academic, behavioral, ethical, and relational".

\section{Challenges of evolving acceptable educational curriculum to curb violence:-}

A modified educational curriculum with emphasis on peace education is long overdue in Nigeria However, there are basic challenges that must be overcome to ensure that it achieves that stated objective or enhancing the capacity to curb terrorism in Nigeria. The first challenges is the issue connected with planning, designing and implementing a modified educational curriculumas there is apparent lack of clear understanding of what it should containamong significant majority of actors involved in the process due to religious and ethnic differences. The actors include government agencies, traditional institution, religious bodies, parents, pupils and schools and if the curriculum is not devoid of ethnic or religious sentiment, it might not yield the expected result

Second, there is lack of unity of purpose or consensus among political leadership on what is best for Nigeria.This is as a result of jaundiced and perverted as well as narrow way the political leadership views and decides on issues of national important based on ethnic, religious and political imperatives. This informed Abdu'l-Bahá, 1961:130)to observe concerning religion that:

"It should unite all hearts and cause wars and disputes to vanish from the face of the earth; it should give birth to spirituality, and bring light and life to every soul. If religion becomes a cause of dislike, hatred and division it would be better to be without it, and to withdraw from such a religion would be a truly religious act....Any religion which is not a cause of love and unity is no religion".

This is equally true of the divisive role played by political ethnicity that becloud spirit of nationalism while political imperatives are given more consideration than oneness of the nation. By implication, political leaders in Nigeria use ethic and religious cleavages as a spring board for mobilization of the masses for selfish agenda rather than uniting them. Hence, to evolve an acceptable curriculum might be a difficult challenge. For instance, the rumour of removal of Christian Religious study from secondary school educational curriculum nearly created a friction between the government and the two major religions in Nigeria in June/July 2017.

Third, the training and retraining of teachers and instructors who are to impact knowledge might impede the success of implementing a new curriculum. Part of the issue to contend with is whether the teachers are convinced of the justification for the training needs as to internalize it and convincingly communicate such to the pupils. It is however sad that many training programs in the public service have not achieved the objectives as the trainees were concerned with allowances associated with the programme rather than the knowledge to be acquired (Graham 1983:183).

Fourth, the lack of political will by government due to extraneous consideration to satisfy sectional interest at the expense of national interest might complicate the task of evolving a modified educational curriculum to curb terrorism. This was demonstrated by Alao (2012) and Ekong (1983:87) among others that government often willfully refused to do the needful to curb violence. Also, political leadership benefit richly from crisis ridden society on account of war economy as contained in The Sun (2016) and The Guardian (2015) is often used for political mobilization to set one group against the other. In effect, peace education may not be to their best interest.

In addition, the resources required for such endeavour might not be readily available or be released by government as well as the issue of misappropriated due to high level of corruption. There is also the tendency for extremist in government or outside it to hijack the process due to private interest if not properly monitored. Also, if the message by parents and religious body contradict that of the school, there is the tendency to get the pupils confused or not to trust the system. This has the tendency of rendering all the resources and energy committed to be a wasteful exercise. 
The sustainability of modifying educational curriculum could be a challenge as it is not a one-time touch but a continuous process. It is painstaking and a long time project which requires commitment, sincerity of purpose and devoid of excessive political interference. This implies that result is not instantaneous while patience, monitoring, evaluation and re-evaluation is the rule of game.

\section{Conclusion and Recommendations:-}

The study concludes that there is inherent defect in Nigerian educational curriculum with specific reference to inculcating values that support peace and enhance the capacity to curb Boko Haram in the Northern part of Nigeria. It is therefore imperative and long overdue that the educational curriculum need be modified to accommodate peace education at all levels which is expected to inculcate peace values in pupils and students.

For the success of evolving a modified and successful educational curriculum that will accommodate peace education and possess the capacity to curb terrorism, the study recommended that:

1. The process must be inclusive in a sense that all the necessary actors in the educational sector must be involved and accommodated. This process will help to engaging whole communities in builda culture of peace and healing.

2. The study recommends the introduction of leadership for peace program in Nigeria. This is expected to sensitize political leaders to support the need for modified educational curriculum with peace education given a prominence.

3. It is recommended that the development of a modified educational curriculum be made in the children's mother tongue particularly at the primary school level to aid deeper absorption of the content that could be developed later in life.

4. The modified educational curriculum with peace content alone is not sufficient to curb terrorism while the home, religious instruction and Non-Governmental Organizations (NGO) among others must be supportive of peace education and at informal level, the citizenry at large.

\section{References:-}

1. Abed al a'al, M. (1994:22) The Crime of Terrorism. Comparative Study. Cairo: Dar al Nahda,

2. Abduraham, I. and Tar, U.A. (2008) "Conflict Management and Peacebuilding in Africa: the Role of State and Non State Agencies".. Information, Society and Justice Vol. 1 No, 2, June pp 185-202.

3. Buari, J. (2015). "Army: Boko Haram Use Child-Soldiers, Human Shields". Naijcom cited in https://www.naij.com/321089-army-boko-haram-use-child-soldiers-human-shields.html. Retrieved 18/8/17

4. ACS Distance Education (2011) "What is Education" cited in https://www.acs.edu.au/info/ education /trendsopinions/what-is-education.aspx. Retrieved 21/08/17

5. Alao, David Oladimeji (2016). "Interrogating Corruption as an Albatross in Curbing Protracted Conflicts and Terrorism in Nigeria”. Babcock Journal of History and International Studies, Vol. 3. No. 1. November, 2016.

6. Alao, David Oladimeji, Atere Clement Olusegun and Alao, Oluwafisayo (2012) Boko-Haram

7. Insurgence in Nigeria: The Challenges and Lessons. Oman Journal of Business and Management Review. Sept. Issue Vol 2 (2).

8. Alao, D.O (2012). "An Evaluation of Mechanisms Adopted in Managing Ethno-Communal Conflicts in Africa: Saare/Tsaragj Kwara State, Nigeria”. African International Journal of Social Policy and Administration, Vol. 5 Number 1 Center Global Counterterrorism Cooperation (2013) "The Role of Education in Countering

9. Violent Extremism Meeting Note" December .cited in globalcenter.org/wp-

10. content/uploads/.../Dec13_Education_Expert_Meeting_Note.pdf. Retrieved 26/08/17.

11. Chazin, K.T. \& Ledford, J.R. (2016). Practices and procedures related to reinforcement. In Evidence-based instructional practices for young children with autism and other disabilities. Retrieved from http://vkc.mc.vanderbilt.edu/ebip/reinforcement

12. Clark, M. (2016) "UNESCO promotes Global Citizenship Education” A UN Seminar under the auspices of UNESCO Liaison Office in New York (15/09/160 cited in http://www.unesco. org/new/en/unesco-liaisonoffice-in-new-york/about-this-office/singleview/news/ unesco

13. promotes-global_citizenship_education_at_un_seminar/. Retrieved 28/08/17.

14. Cunningham, Jr. W G (2003) "Terrorism Definitions and Typologies" in Terrorism: Concepts, Causes, and Conflict Resolution. Cited in http://terrorism.about.com/od/causes /a/ causes_terror.htm. http://terrorism.about.com/od/causes/a/causes_terror.htm. 
15. Danesh, H.B. (2011) “Towards an Integrative Theory of Peace Education” in Danesh, H. B. (2011:30) Danesh, H. B. (2011) "Education for Peace Reader" Education for Peace

16. Integrative Curriculum Series. Series 4. Victoria, Canada: EFP Press.

17. Danesh, H. B. (2011:22) "Education for Peace Reader" Education for Peace Integrative Curriculum Series. Series 4. Victoria, Canada: EFP Press.

18. Danladi, E. N. (2008). Alleviating Poverty in Nigeria: The role of Social Studies Education (A workshop paper presented at FCT- CDE, Zuba).

19. Danesh H. B. (2006). Towards an Integrative Theory of Peace Education. Journal of Peace

20. Education. 3(1) 55-78

21. Dewey, J.. (1897). "My pedagogic creed.” The School Journal 54(3): 77-80. Einstein, A. (1988) On Peace. Random House Value Publishing (first published October 1st 1967)

22. Ekong, E.E. (1983:87) "Problems of Staff Training and Development in Nigeria Public Sector: A Case Study of Enugu State Civil Service”. Nigerian Quarterly Journal of Administration. Vol.

23. XV11, No 3\&4. 81-105.

24. Fisher, S, Ludin, J., Williams, S, Abdi, D.I., Smith R., and Williams, S. (2000). Working with

25. conflict: skills and strategies for Action. London: Zed Books.

26. Galtung, J. (2000). Conflict Transformation by Peaceful Means. New York: United Nations. p.16 in Nicolaides, D. (2008) Employing Conflict Transformation in Understanding the Cyprus

27. Problem: Prospects and Instruments in Conflict Transformation. A Master of Arts Degree Thesis in Peace and Conflict Studies European University Centre for Peace Studies. p. 11.

28. Galtung, J. (1990). 'Cultura Violence'. In Journal of Peace Research, 27:3 Ross, M. (1993). The Management of Conflict: Interpretations and Interests in Comparative Perspective. New

29. Haven: Yale University Press.

30. Goldman, D. (2015). "The Misplaced Fear of Religion in Classrooms" The Atlantic Daily cited In https://www.theatlantic.com/education/archive/2015/10/the-misplaced-fear-of-religionin-classrooms/411094/. Retrieved on 21/08/17.

31. Goodhand, J. (2006). Aiding Peace?, the Role of NGOs in Armed Conflict. In ITD Graham, H.T. (1987:87). Politics, Man Power Development. London: Pitman Publication 183.

32. Guidelines Version 1.0 (2010). What is meant by the term curriculum?" National Center of Universal Design for Learning. Cited in http://www.udlcenter.org/aboutudl/udlguidelines. Retrieved on 21/08/17.

33. Hamid , A. (2012). Purpose of Education 10 October, cited in http://aishahamid26.blogspot .com.ng/2012/10/purpose-of-education.html. Retrieved 25/08/17.

34. Harris, Ian. (2002). "Conceptual underpinnings of peace education.” In Gavriel Salomon and Baruch Nevo (Eds.). Peace education: The concept, principles, and practices around the world. NJ: Lawrence Erlbaum Associates. 20.

35. Hoffman, (1998). Inside Terrorism. Columbia University Press. p. 32. ISBN 0-231-11468-0. See review in "Inside Terrorism". The New York Times.

36. Horny, A.S. (2006). Oxford Advanced learner's Dictionary, International Students, Edition, 7th Edition Oxford: University Press

37. Kdijah, C. (2016). "The Role of Politics in Curriculum Decision Making". Curriculum Studie cited in https://www.slideshare.net/kdijah/the-role-of-politics-in-curriculum-decision-making. Retrieved 18/06/17.

38. Kimbre, L. (2016)" The Four Stages of Curriculum Development" Brookhaven Innovation

39. Academy. Cited in https://lauriekimbrel.wordpress.com/2016/07/06/the-four-stages-of curriculum-development/ Retrieved 21/08/17

40. Salih, M. A (2013) Education's Role In Combating Terrorism, Violence and Extremism in Iraq" University of Peace, Peace and Conflict Monitor. Cited in http://www.monitor.upeace .org/innerpg.cfm?id_article=972. Retrieved 26/08/17.

41. Stabback, P. (2016) What Makes a Quality Curriculum? In-Progress Reflection N ${ }^{\circ}$ on Current and Critical Issues in Curriculum and Learning. International Bureau of Education. http://unesdoc.unesco.org/images/0024/002439/243975e.pdf Retrieved on 26/08/2017.

42. THE GUARDIAN (2015) BUHARI RECEIVES REPORT ON ARMS CONTRACTS UNDER YAR'AdUA, JONATHAN. CITED in uardiannews

43. The Nations News Paper (August 28). Boko Haram 'Commander': I led Chibok Schoolgirls Kidnap.

44. The Sun (2016) BREAKING: FG releases information on recovered loot. Cited in http:// unnewsonline.com/ breaking-fg-releases-information-on-recovered-loot/.Retrieved 27/06/16.

45. UNESCO (2017) "Preventing violent extremism through education: A guide for policy-makers" 
46. United Nations Educational, Scientific and Cultural Organization. Cited in unesdocunesco.org/images/0024/002477/247764e.pdf. Retrieved 26/08/17.

47. UNESCO, 2015, Global Citizenship Education: Topics and Learning Objectives.http:// unesdoc.unesco.org/images/0023/002329/232993e.pdf. Retrieved on 19 November 2016.

48. UNICEF (2011) Peace Education. Cited in https://www.unicef.org/education/focus_ peace education.html. Retrieved 22/08/17

49. Wheat, T. (2011). The Difference Between Terrorists and Insurgents in http://www.worldreport news .com/usforeign-policy-archived/the-difference-between-terrorists-and-insurgents. 